\title{
Determining integral permeability of undermined coal rock mass in closed mines
}

\author{
Oleksii Prykhodchenko ${ }^{1, *}$, Svitlana Prykhodchenko ${ }^{1}$, and Larysa Tokar $^{2}$ \\ ${ }^{1}$ Institute of Geotechnical Mechanics named by N. Poljakov of National Academy of Sciences of \\ Ukraine, 49005, Dnipro, Simferopolska Str., 2a, Ukraine \\ ${ }^{2}$ National Technical University Dnipro Polytechnic, 49005, Dnipro, Dmytra Yavornytskoho Ave., 19, \\ Ukraine
}

\begin{abstract}
Effect of mining on pressure variation in coal rock mass has been analyzed. Methods to determine integral permeability as well as fluid pressure variations within undermined coal rock mass have been proposed. A technique to identify zones of "fast" gas and "slow" gas within undermined formation has been considered.
\end{abstract}

\section{Introduction}

It has been determined recently that while extracting methane from coal mines, maximum gas amount can be captured by means of holes from coal rock mass undermined in the process of coal mining. Formation of technogenic methane accumulations results from subsidence of roof rocks, their softening as well as free gas and liberated gas emission to mine workings, and fractured zones of the coal rock mass [1,2]. Gas pressure declines and permeability of coal rock mass varies due to the undermined formation softening, and partial methane emission [3]. Determination of pressure variation within rock mass is an important problem [4] since it will help identify residual methane reserves, the rock mass permeability, and parameters of degassing holes.

\section{Methods}

Direct measures by means of formation tests while hole drilling is the most accurate technique to determine pressure within undermined coal rock mass; however, they are rare event for practice.

Paper [5] proposes a method to measure gas pressure in the undermined coal rock formation. After subsidence of roof rocks, certain share of methane drains into mine workings from the undermined formation; certain share remains in the rock mass which results in pressure variation. As it has been demonstrated in paper [6], there is a tendency for the increase in pressure of fluids, saturating sandstones, up the open-cut from a coal seam mined previously. In the neighbourhood of the undermining zone, gas pressure should be $80-90 \%$ of hydrostatical one; while approaching mined-out coal seam, pressure declines down to atmospheric one at the boundary of a mine working. Linear dependence of fluid pressure variation within the undermined rock mass $P_{\text {u.r.m. }}(\mathrm{Pa})$ has been proposed; the

\footnotetext{
*Corresponding author: gvrvg@meta.ua
} 
dependence is expressed as the function:

$$
P_{u . r . m}=f(h),
$$

where $h$ is distance along the normal from the mined-out coal seam floor up to the sandstone where pressure is measured.

Pressure variation within the softened coal rock mass above the mined-out seam is shown using the dependence:

$$
P_{u . r . m}=a \cdot h \cdot \gamma_{v} \cdot g
$$

where $\gamma_{v}$ is water density being equal to $1000 \mathrm{~kg} / \mathrm{m}^{3} ; g$ is gravity factor, $\mathrm{m} / \mathrm{s}^{2}$; and $a$ is coefficient involving effect of undermining zone height.

Coefficient $a$ is identified for each hole; it depends upon undermined coal rock mass height as well as upon fluid pressure within a zone where the formation starts its softening:

$$
a=\frac{0.85 \cdot H_{n}}{h_{m}},
$$

where $H_{n}$ is depth of upper boundary of a zone of undermining effect (from the surface), $\mathrm{m}$, and $h_{m}$ is height of undermining zone effect (from the undermined seam), $\mathrm{m}$.

Hence, when the method is used to determine dependence of pressure variation for each hole, it becomes possible to calculate values of integral permeability for the undermined coal rock mass.

The method, intended to measure fluid pressure, is correct for a case when pressure in the neighbourhood of the mined-out seam floor is $0.1 \mathrm{MPa}$, i.e. during certain period after the coal seam development. With the course of time, migration of fluids takes place towards rock mining within the undermined coal rock mass; in this context, pressure is balanced in the rock mass disturbed by fissures.

Pressure variation within the undermined rock mass can also be determined using a method based upon hydrostatic pressure and static pressure determination according to water levels in a hole [5] if hydrogeological observations during hole drilling involved registration of both static water levels and depths at which measurements were carried out.

Static pressure in a hole (according to water level $P_{\text {st.p }}(\mathrm{Pa})$ was determined on the formula:

$$
P_{s t . p .}=\left(H-h_{s t . l}\right) \cdot \gamma_{v} \cdot g
$$

where $h_{\text {st.l. }}$ is static water level in a hole, $\mathrm{m}$; and $H$ is seam depth, $\mathrm{m}$.

Hydrostatic pressure $P_{h . p}(\mathrm{~Pa})$ was measured in a hole for the depths where static levels were determined. Following formula was applied:

$$
P_{h . p .}=H \cdot \gamma_{v} \cdot g
$$

Further coefficient of static pressure decline in a hole $\left(k_{s . p . d}\right)$ was determined. The coefficient demonstrates relative pressure deviation from hydrostatic pressure using the formula:

$$
k_{s . p . d}=\frac{P_{s t . p}}{P_{h . p}} .
$$

According to the methods, dependences of pressure variation as well as integral 
permeability of the undermined coal rock mass were determined in the context of series of holes drilled on the undermined coal rock mass.

\section{Results and discussion}

The studies were carried out in the context of series of holes in the field of O.F. Zasiadko mine which redrilled mined-out seam $n_{l}$.

In the context of each hole, height of undermining effect was calculated, dependence of pressure decline relative to a mine working was determined as well as integral permeability; moreover, hydrogeological data were applied to identify coefficient of static pressure decline.

Hole 3431. Mineable thickness of the undermined coal seam is $1.5 \mathrm{~m}$. Volatile-matter content $V^{d a f}$ is $40.6 \%$. Height of undermining rock effect $h_{m . n .}$ is $97 \mathrm{~m}$. Dependence of gas pressure variation within the undermined rock mass in the neighbourhood of a hole is expressed as follows:

$$
P_{u, r . m}=0.25 \cdot h \cdot \gamma_{v} \cdot g
$$

The generated equation makes it possible to calculate gas pressure within the undermined formation and, taking into consideration previously carried out studies [7], to observe changes in the rock mass permeability. As a graph demonstrates (Fig. 1, a), integral permeability increases dynamically from $310 \mathrm{~m}$ mark to $330 \mathrm{~m}$ mark being almost $100 \cdot 10^{-15} \mathrm{~m}^{2}$.

According to values of static pressure decline coefficient, a graph was plotted (Fig. 1, b). At $250 \mathrm{~m}$ mark, $k_{\text {s.p.d. }}=0.97$; its values lower while the mined-out coal seam approaching. In such a way, within analytical boundary of undermining zone beginning, $k_{\text {s.p.d. }}=0.94$; it becomes $0.8-0.81$ at $342 \mathrm{~m}$ remaining invariable through to the mined-out seam.

Thus, comparison of the graphs of changes in integral permeability and a graph of static pressure decline has explained that the values decrease in terms of the same intervals. That helps conclude that the both methods have identified two zones in the undermined coal rock mass: "slow gas" zone $(280$ to $320 \mathrm{~m})$, corresponding to $3^{\text {rd }}$ and $4^{\text {th }}$ zones according to M.A. Iofis [8], and "fast gas" zone (320 to $378 \mathrm{~m})$ corresponding to $1^{\text {st }}$ and $2^{\text {nd }}$ zones. In compliance with paper [9], methane from "fast gas" zone gets to operating longwall sometimes twice and more times increasing gas content; and methane from "slow" gas zone drains slowly to the mined-out area increasing background concentration.

Hole 3844 (Fig. 2). Mineable thickness of the undermined coal seam is $1.0 \mathrm{~m}$. Volatilematter content $V^{\text {daf }}$ is $40.6 \%$. Height of undermining rock effect $h_{m . n}$. is $65 \mathrm{~m}$. Dependence of gas pressure variation within the undermined rock mass in the neighbourhood of a hole is expressed as follows:

$$
P_{u, r . m}=0.28 \cdot h \cdot \gamma_{v} \cdot g
$$

Integral permeability of rock mass (Fig. 2) in the neighbourhood of the hole starts increasing vigorously from $240 \mathrm{~m}$ to $250 \mathrm{~m}$ becoming $250 \cdot 10^{-15} \mathrm{~m}^{2}$. Hence, after $240 \mathrm{~m}$, the undermined coal rock mass turns out to be more disturbed due to the increasing fissure number. The theoretical calculations have been substantiated by means of static pressure decline calculations. As graph in Figure 2, b shows, $k_{\text {s.p.d. }}$ values do not vary down to $248 \mathrm{~m}$ depth being $0.95-0.96$; then, they decrease rapidly and $k_{\text {s.p.d. }}$ is 0.23 at $259 \mathrm{~m}$ mark. Thus, "slow" gas zone (i.e. 212-248 m), and "fast" gas zone (i.e. 248-277 m) can also be identified in the neighbourhood of the hole. 
a

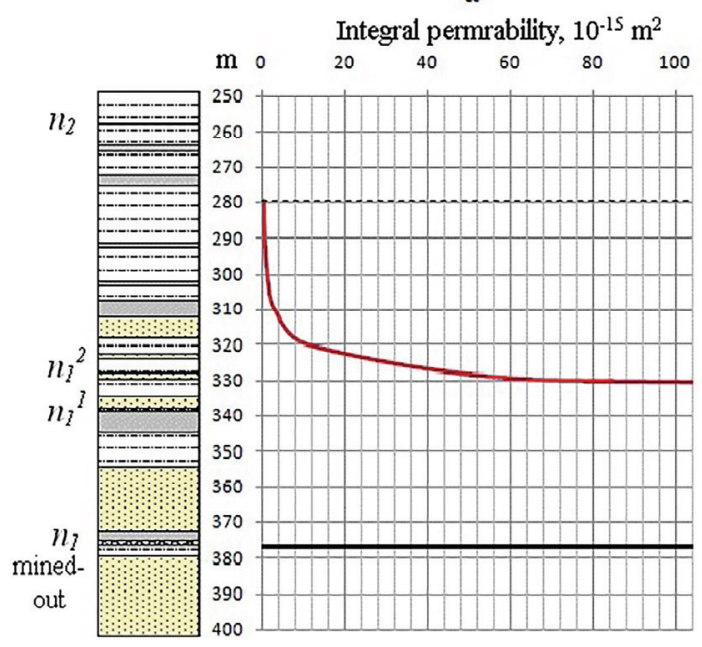

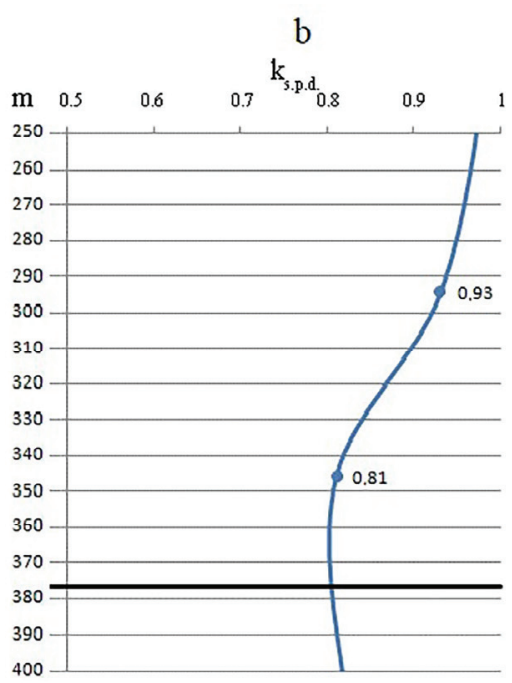

Fig. 1. Integral permeability (a) and static pressure decline coefficient (b) variation depending upon the depth of sandstones of the disturbed coal rock mass above the mined-out seam $n_{1}$ in the neighbourhood of hole 3431 drilled in the field of O.F. Zasiadko mine.

a

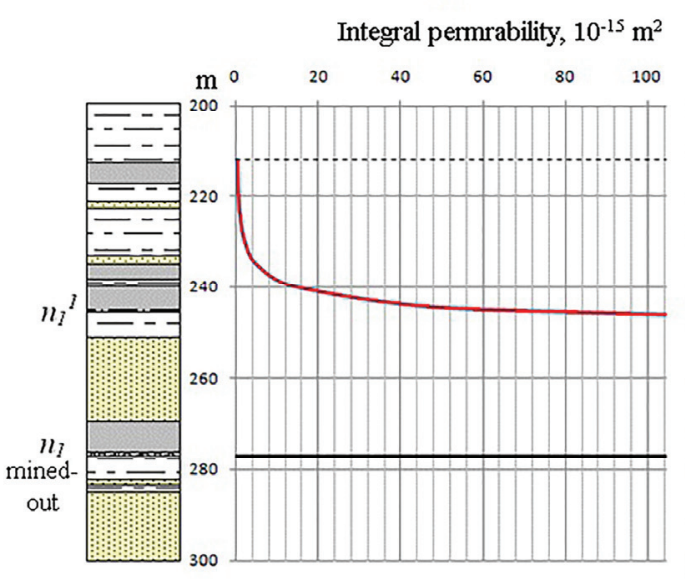

$\mathrm{b}$
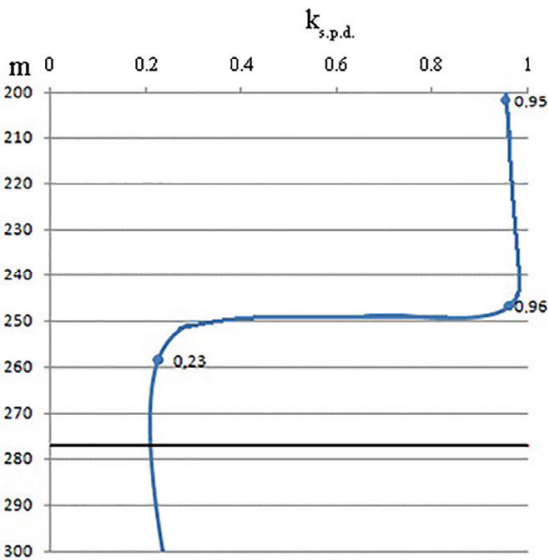

Fig. 2. Integral permeability variation (a) and static pressure decline coefficient (b) variation depending upon the depth of sandstones of the disturbed coal rock mass above the mined-out seam $n_{1}$ in the neighbourhood of hole 3844 drilled in the field of O.F. Zasiadko mine.

Hole D-5 (Fig. 3). Mineable thickness of the undermined coal seam is $1.5 \mathrm{~m}$. Volatilematter content $V^{\text {daf }}$ is $40.6 \%$. Height of undermining rock effect $h_{m . n}$ is $97 \mathrm{~m}$. Dependence of gas pressure variation within the undermined rock mass in the neighbourhood of a hole is expressed as follows:

$$
P_{u, r . m}=0.25 \cdot h \cdot \gamma_{v} \cdot g
$$

Analytical values of integral permeability within the undermined formation in the neighbourhood of D-5 hole have shown that the fastest permeability increase starts from $520 \mathrm{~m}$ depth (Fig. 3, a). 
a

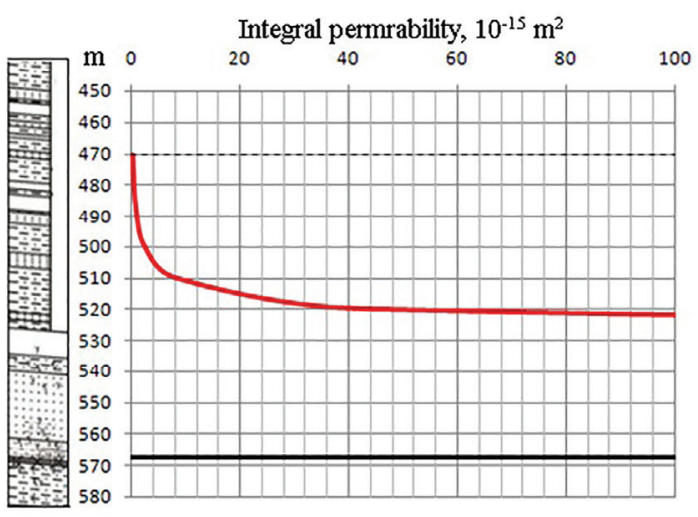

b

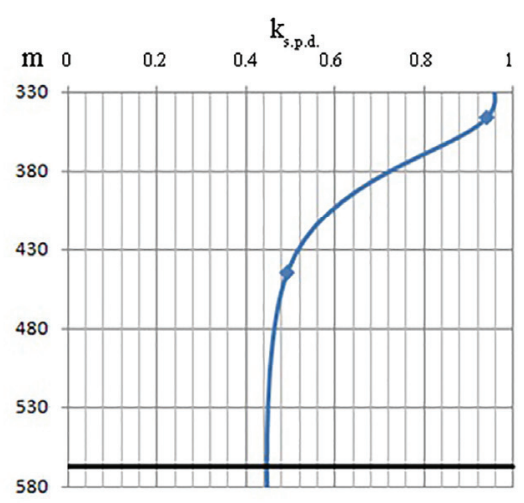

Fig. 3. Integral permeability variation (a) and static pressure decline coefficient (b) variation depending upon the depth of sandstones of the disturbed coal rock mass above the mined-out seam $\mathrm{n}_{1}$ in the neighbourhood of hole 3431 drilled within a site of Kalmiusski Rudnik of O.F. Zasiadko mine field.

The calculations are supported by the fact that while hole drilling, $100 \%$ lost returns began starting from $530 \mathrm{~m}$ depth. However, comparison of permeability variation graph and statistic level decrease graph (Fig. 3, b) has shown that the zones do not coincide to compare with the two previous holes. In the context of the hole, $k_{\text {s.p.d. }} \mathrm{B}$ deviation from values, close to 0.9 , starts from $350 \mathrm{~m}$ mark; decrease in the coefficient values stop approaching $0.45-0.5$. Such a variation can be explained by the differences between analytical height of undermining effect zone, and natural one.

\section{Conclusions}

Hence, the listed methods help forecast integral permeability as well as fluid pressure variations within the undermined coal rock mass making it possible to identify zones of "fast" and "slow" gas zones, and determine parameters to evaluate and extract methane reserves from the undermined coal rock mass.

\section{References}

1. Lukinov, V.V., Bezruchko, K.A., Prykhodcheko, O.V., Shpak, V.Yu. (2012). Forecast promising areas for searching accumulations of free methane (for example mine "Butovska"). Naukovyi visnyk Natsionalnoho hirnychoho universytetu, (2), 27-35

2. Prykhodchenko, V.F., Sdvyzhkova, O.O., Khomenko, N.V., Tykhonenko, V.V. (2016). Effect of time-transgressive faults upon methane distribution within coal seams. Naukovyi visnyk Natsionalnoho hirnychoho universytetu, (1), 31-35

3. Lukinov, V., Prykhodchenko, V., Prykhodchenko, A., Tokar L. (2014). Mining and geological conditions of methane redistribution within the under-mined coal-rock massif. London: CRC Press, 317-325

4. Savchuk, V., Prykhodchenko, V., Buzylo, V., Prykhodchenko, D., Tykhonenko, V. (2013). Complex use of coal of Northern part of Donbass. Annual Scientific-Technical Collection Mining of Mineral Deposits. The Netherlands: CRC Press, 185-191

5. Lukinov, V.V., Klets, A.P., Prikhodcheko, A.V., Tikhonov, A.A. (2010). Fluid pressure and estimation of integral permeability variation within the undermined coal rock mass. 
Naukovyi visnyk Natsionalnoho hirnychoho universytetu, (5), 106-110

6. Lukinov, V.V. (2006). Methane of closed down mines - problems and solution Geotekhnicheskaya mekhanika: Mezhvedomstvennyy sbornik nauchykh trudov, (67), 5567

7. Lukinov, V.V., Klets, A.P., Bobryshev V.V. (2002). Filtration parameters of reservoir rock - coal rock mass, undermined by mine workings. Geotekhnicheskaya mekhanika: Mezhvedomstvennyy sbornik nauchykh trudov, (37), 74-79

8. Iofis, M.A., Shmelev, A.I. (1985). Inzhenernaya geomekhanika pri podzemnykh razrabotkakh - Moskva: Nedra

9. Lukinov, V.V., Fichev, V.V., Klets, A.P. (2002). Principles to estimate methane reserves being extracted from the undermined coal rock formation. Geotekhnicheskaya mekhanika: Mezhvedomstvennyy sbornik nauchykh trudov, (32), 30-40 